\title{
Acetylcholinesterase Biosensors for Electrochemical Detection of Organophosphorus Compounds: A Review
}

\author{
Vikas Dhull, ${ }^{1}$ Anjum Gahlaut, ${ }^{2}$ Neeraj Dilbaghi, ${ }^{1}$ and Vikas Hooda ${ }^{2}$ \\ ${ }^{1}$ Department of Bio \& Nanotechnology, Guru Jambeshwar University of Science \& Technology, Hisar 125001, India \\ ${ }^{2}$ Centre for Biotechnology, Maharshi Dayanand University, Rohtak 124001, India \\ Correspondence should be addressed to Vikas Hooda; vikas.cbtmdu@gmail.com
}

Received 23 July 2013; Accepted 3 October 2013

Academic Editor: Seiji Shibasaki

Copyright (c) 2013 Vikas Dhull et al. This is an open access article distributed under the Creative Commons Attribution License, which permits unrestricted use, distribution, and reproduction in any medium, provided the original work is properly cited.

\begin{abstract}
The exponentially growing population, with limited resources, has exerted an intense pressure on the agriculture sector. In order to achieve high productivity the use of pesticide has increased up to many folds. These pesticides contain organophosphorus (OP) toxic compounds which interfere with the proper functioning of enzyme acetylcholinesterase (AChE) and finally affect the central nervous system (CNS). So, there is a need for routine, continuous, on spot detection of OP compounds which are the main limitations associated with conventional analytical methods. AChE based enzymatic biosensors have been reported by researchers as the most promising tool for analysis of pesticide level to control toxicity and for environment conservation. The present review summarises AChE based biosensors by discussing their characteristic features in terms of fabrication, detection limit, linearity range, time of incubation, and storage stability. Use of nanoparticles in recently reported fabrication strategies has improved the efficiency of biosensors to a great extent making them more reliable and robust.
\end{abstract}

\section{Introduction}

At present pesticides play a major role in agriculture. Pesticides have the insecticidal property due to which they are in great use $[1,2]$. But human health and the surroundings are affected by these pesticides as they contain the toxic compounds. These toxic compounds are hazardous as they can accumulate in grains, vegetables, fruits, and so forth, percolate in soil, and finally lead to water contamination $[3,4]$. The concentration of these toxic compounds in the environment is increasing day by day with an exponential rate. Organophosphorus (OP) constitutes one of the important classes of toxic compounds which can cause headache, drowsiness, confusion, depression, irritability, disorientation, impaired memory and concentration, speech difficulties, eye pain, abdominal pain, convulsions, respiratory failure, and serious neurological disorders [5-10]. The EPA lists organophosphates as very highly toxic to bees, wildlife, and humans [1]. These OP pesticides inhibit the enzyme acetylcholinesterase (AChE, EC 3.1.1.7) which is involved in the proper functioning of the central nervous system (CNS) of the humans. Due to this inhibition of the enzyme AChE, acetylcholine (ACh) neurotransmitter accumulates in the body which interferes with the muscular responses and finally leads to respiratory problems, myocardial malfunctioning, and even death $[11,12]$. The toxicity of different pesticides depends upon the chemical structure of the pesticides [12, 13]. The repeated low level exposure to OP compounds leads to the acute effect on the health of humans. The contamination of soil and food due to these pesticides has caused a serious concern, so it is necessary to monitor their increasing concentration in the food products of daily use. Soil is known to be a natural purifier in which the OP pesticides along with water interact with the soil particles and do not contaminate ground water, but by the time some of the OP pesticides come forward such as organochlorine pesticides which can even percolate even through the soil and contaminate both ground and surface water. Many rules and regulations have been made on the international level to reduce the contamination of ground and surface water. Regulatory limits and the guideline levels are also there for permissible residues in drinking water [14].

It is necessary to develop the methods which are fast, sensitive, and reliable for the detection of OP pesticides 


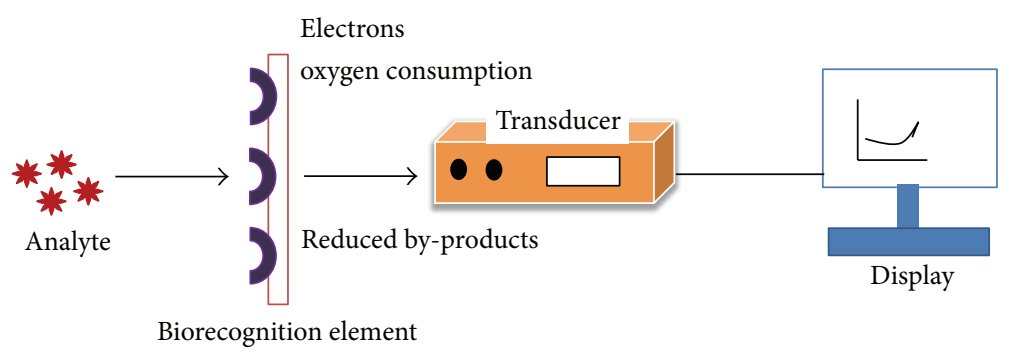

FIGURE 1: Basic principle of electrochemical biosensor.

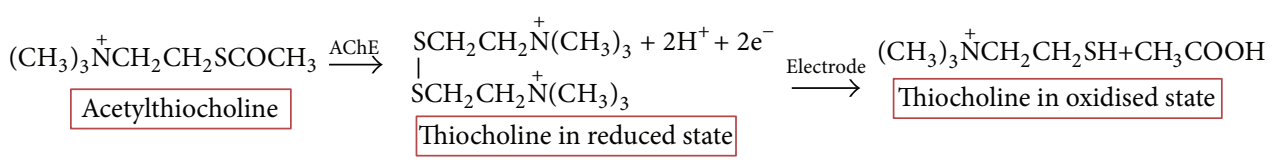

Scheme 1: Reaction involved in generation of electrochemical response biosensor.

in fruits, vegetables, water, and so forth [15]. Conventional analytical methods to monitor the concentration of these acute toxic compounds include capillary electrophoresis [16], colorimetry [17], gas chromatography (GC) [18], mass spectrometry (MS) [19], thin layer chromatography [20, 21], and high performance liquid chromatography (HPLC) [22]. The above said methods have some limitations, that is, sample preparation which is hectic and time consuming; requiring expensive equipments and trained manpower; less economical; and so forth. To overcome the above problems, development of biosensor is being encouraged. They are simple, sensitive, of low developmental cost, and user friendly; a normal person can handle it easily.

The present review describes and discusses the use of AChE biosensors for detection of OP compounds and measurement of toxicity level in different samples.

\section{AChE Based Catalysis}

AChE belongs to the family of carboxylesterase (EC number 3.1.1.7.). It is serine protease and stabilises level of acetylcholine (neurotransmitter) by catalysing the conversion of acetylcholine to thiocholine. AChE is concentrated at neuromuscular junctions and cholinergic brain synapses. When the enzyme is present in the active form it terminates synaptic transmission. AChE is highly efficient and catalyses the breakdown of ACh in microseconds keeping the synaptic cleft clear as to avoid the collision of the messages. AChE has two active subsites, anionic and esteratic subsite. Acetylcholine mediates messages between the nerves which is responsible for muscle contraction. When ACh is released from the nerve into the synaptic cleft, it got recognised by ACh receptors present on the postsynaptic membrane which further transmits signal. Along with the ACh receptors $\mathrm{AChE}$ is also present on the postsynaptic membrane which helps in the termination of the signal transmission by hydrolysing ACh. On hydrolysis, ACh split into two products one is choline and the other is acetic-acid. Choline and acetic-acid are recycled by the body to again form acetylcholine to maintain the reserves of neurotransmitters so that they can be used by the body again during the time of need. In the presence of inhibitor (OP compound), which forms covalent bond with serine present on the active site of AChE, leads to inactivation of the enzyme $[54,55]$, and the muscles involved do not relax, leading to paralytic conditions. The intensity of inhibition of AChE is proportional to the concentration of OP compound, that is, inhibitor, and is also exploited as principle of detection method for concentration of OP compounds [55-58].

\section{Basic Principle of Biosensors}

Biosensor comprises basically of three elements, that is, biological recognition element, transducer, and signal detector as shown in Figure 1. The biological recognition element must be extremely specific to the analyte for the accurate detection of the analyte in different samples. As recognition element and analyte come in close proximity to each other the chemical changes take place in the form of the generation of electroactive species, reduced forms of by-products, consumption of oxygen, and so forth [59]. These changes are detected and displayed on controlling system.

3.1. Principle of OP Biosensor Based on Inhibition Mechanism of $A C h E$. The sensitivity of biosensor relies on the biorecognition layer which catalyses the reaction. The product/byproduct further or itself acts as signal which is directly or inversely proportional to the analyte concentration. In case of AChE inhibition based OP biosensors, the signal generated is inversely proportional to the concentration of OP compound or, in other terms, we can say that increased concentration of OP compound leads to weak signals. The AChE biosensor basically works on the inhibition effect. The biosensor in which the AChE is used as the biorecognition element can detect the toxic organophosphates along with the others such as carbamate pesticides, nerve agents, and several other natural toxins $[60,61]$. Some drugs can also be detected with the help of such biosensors [62]. If the inhibitor is not present in the sample then the acetylthiocholine will be converted into the thiocholine and the acetic-acid. as shown in Scheme 1. But if the inhibitor is present in the sample 


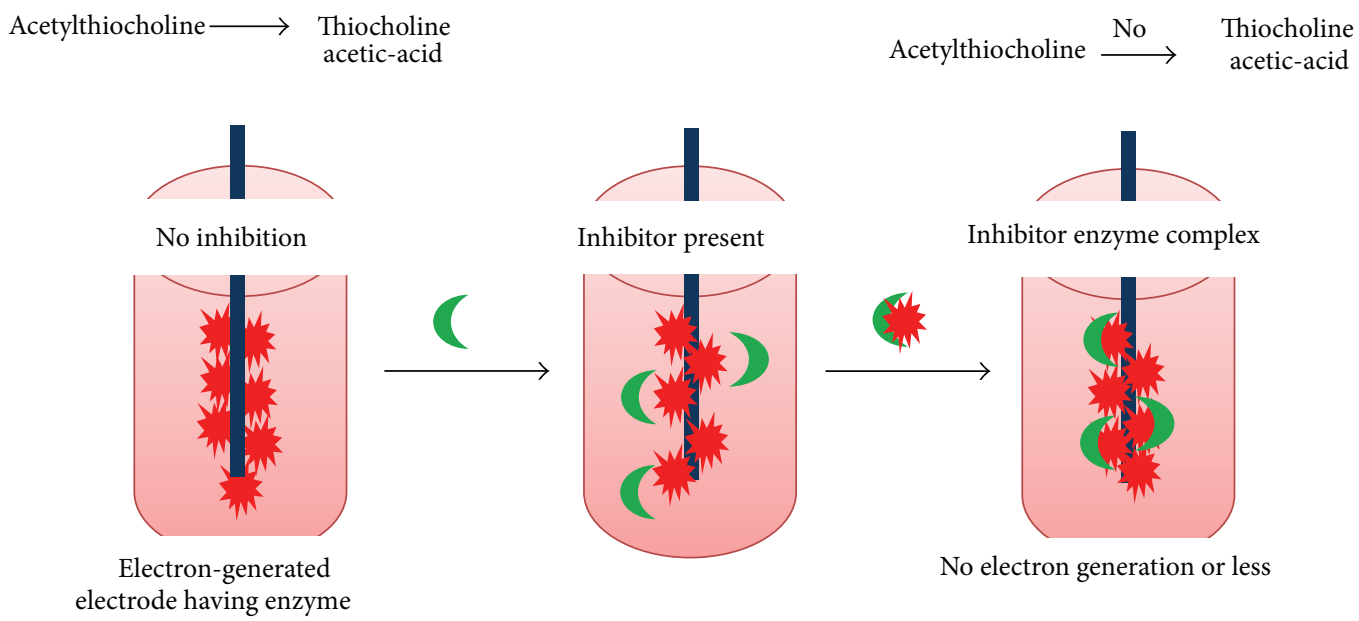

FIgURE 2: Principle of AChE inhibition-based OP biosensor.

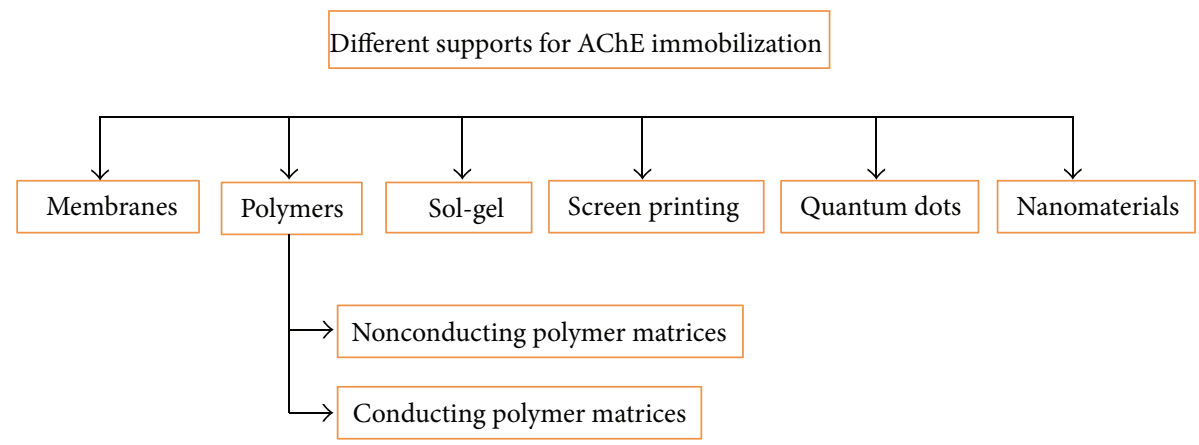

FIGURE 3: Different supports available for fabrication of working electrode.

then the concentration of thiocholine is decreased or no thiocholine and acetic-acid is produced, in other words it completely inhibits the conversion as shown in Figure 2 [63]. Under the influence of applied voltage thiocholine is oxidised. The anodic oxidation current is inversely proportional to the toxic compound present in the sample and the time of exposure.

In the beginning, $\mathrm{AChE}$ biosensors were not considered as reliable tools, but with time the advances in fabrication strategies and methods of enzyme purification and its stabilization have overcome the drawbacks related to accuracy, sensitivity, and reliability [64].

\section{Fabrication of AChE Based OP Biosensor}

In AChE biosensor the working electrode is prepared by attachment of enzyme on different supports. The supports may be matrices, screen-printed electrodes, semiconductors such as Quantum dots (QD), nanomaterial, and so forth [127], as shown in Figure 3. After immobilization of enzyme onto a particular support, conformational changes take place which finally affect the sensitivity, stability, response time, and reproducibility. A variety of methods are available for immobilization of enzymes including physical adsorption, physical entrapment, covalent coupling, self-assembly monolayer, oriented immobilization, and electropolymerisation. Physical adsorption includes the formation of weak bonds such as the Van der Waals forces, and the electrostatic interactions take place between the enzyme and the support that has an advantage of retaining the activity of immobilized enzyme and method is economical. The drawback associated with this method is the leakage of enzyme [79]. In physical entrapment, AChE enzyme is confined within the gel, the matrices, or in the membranes and used for fabrication of working electrode. This is a one-step procedure which is carried out at low temperature, is simple and cheap, without hampering the activity to enzyme. This method also suffers from leaching of enzyme, nonspecific immobilization, and lower reproducibility. In covalent coupling, stable covalent bond is formed between the support and the enzyme that prevents leaching of enzyme, enzyme is in direct availability for interaction with the analyte that further leads to quick response time. But this method involves a high amount of 
enzyme usage, is prone to denaturation, is also expensive, and involves complex procedures $[42,96]$. In case of selfassembled monolayer (SAM) the molecules are organised in the form of monolayer. These molecules have the head group and also a tail group having functional groups; head group has affinity towards the substrate. This layer is easy to prepare, molecules are present in the ordered manner, and size is also within the range of nanoscale. Drawbacks of this method are includes difficulties in reproduction and fouling of electrode takes place with time due to the weakening of interaction between the enzyme and the electrode $[115,116]$. Oriented immobilization is among one of the new methods which can be used. In this method the particular functional groups of the enzymes are exploited and it is possible to orient the active site of the enzyme towards the analyte. This technique requires less quantity of enzyme with specific control over the orientation [117]. Electropolymerization is also one of the possible methods for the immobilization of the AChE enzyme in which the electric field is used for the polymerization.

4.1. Membranes Used in Fabrication of OP Biosensor. In membrane based AChE biosensors the enzyme is immobilized on the suitable matrices. The membranes which are used as support for immobilization can be natural or artificial. The enzyme is confined to the semipermeable membrane which will allow the passage of the substrate through it. The sensitivity and the selectivity of the membrane based biosensors can be enhanced due to the biocompatibility of the artificial membranes. Different supports have been used for the immobilization of enzyme (Table 1), such as nylon and cellulose nitrate [23], glass/sol-gel/polyvinylidene fluoride [24], hybrid mesoporous silica [25], poly-(acrylonitrilemethylmethacrylate-sodium vinylsulfonate) (PAN) [26, 27], cellophane [28], poly(2-hydroxyethyl methacrylate) membrane [29], polyvinyl alcohol(PVA)/SbQ [30], polyacrylamide [31], bio-immunodyne membrane [118], $\mathrm{Si}_{3} \mathrm{~N}_{4} / \mathrm{Ti}$ layer [32], pore glass $/ \mathrm{H}^{+}$membrane electrode [33], and hybond $\mathrm{N}^{+}$membrane [34]. The artificial membranes are selective for the different biomolecules, and as they are highly flexible the response can be enhanced. Membranes are durable and stable on a wide range of $\mathrm{pH}$. The above biosensors suffer from the problem of membrane fouling. The pores of semipermeable membranes are blocked which may lead to hindrance in the passage of solute.

4.2. Polymers Used as Immobilization Support. Polymers can also be used as the support for the enzyme immobilization. The physical and chemical properties of the polymers vary in the wide range which can be exploited for the sensor development [119]. Scince polymer supports are flexible, biologically compatible and of low cost, they have advantage over the other supports. They can be used as free standing film for the biosensor fabrication [120].

4.2.1. Nonconducting Polymer Matrices for Enzyme Immobilization. The nonconducting polymer supports can easily be prepared in the lab. The variety of the functional groups can be generated on these supports by the chemical treatment. The functional groups of interest according to the particular enzyme can be synthesized on such supports. The life of the enzyme can also be enhanced by this method as it provides a microenvironment to the enzyme and can be stored for a long duration. But there are drawbacks with nonconducting polymers, being a support it acts as a barrier between electron and transducer which thus influences the sensitivity of electrode due to which working of electrode is affected. Some supports which are used for immobilization of enzymes are (Table 2) multiwalled carbon nanotubes (MWCNTs)/PAN/Pt electrode [26], PAN/gold nanoparticles (AuNPs) decorated Pt electrode [27], mesocellular silica foam (MSF)-PVA/glassy carbon electrode (GCE) [35], PVA-SbQ polymer decorated screen-printed electrode (SPE) [36], PVA-SbQ/Pt electrode [30], polyamidoamine (PAMAM)- Au/carbon nanotubes (CNTs)/GCE [37], MSF/PVA/GCE [38], nylon net [39], PVA/ azide-unit water pendant (AWP) [121], and CoPC modified PVA-AWP electrode [40].

4.2.2. Conducting Polymer Matrices Used for Enzyme Immobilization. The conducting polymers are the polymers which are synthesized by the chemical and the electrochemical method. The properties of these polymers can easily be adjusted according to the need such as the thickness of film, functionalization, conductivity, and so forth. They can also be used for the enzyme entrapment during electropolymerization and used in the uniform covering of the electrode surface having substrate of any shape and size with the help of the polymer film [122, 123]. Different supports which are used for immobilization of enzymes are (Table 3) poly-(acrylamide)/pH electrode [31], polyethylenimine (PEI)/GCE [41], PEI/SPE [42], mercaptobenzothiazole/polyaniline (PANI)/Au electrode [43], PANI/CNTs coated with single stranded DNA (ssDNA)/Au electrode [44], AuNP-polypyrrole (PPy) nanowire/GCE [45], PPy and PANI copolymer dopped MWCNTs/GCE [46], Silk fibronin matrix [47], CS/ALB/GCE [48], PB/GCE [49], GnPs/Chitosan/GCE [50], polymeric enzyme electrode [51], $\mathrm{ZrO}_{2} / \mathrm{SPE}$ [52], and Gold ( $\mathrm{Au}$ ) nanoparticles/poly(dimethyldiammonium chloride) (PDDA) protected Prussian blue (PB) matrix [53]. The conducting polymers suffer from demerits of high cost, difficult in processing, lack of mechanical stability after doping, difficult to fabricate, short life span, and so forth.

4.3. Sol-Gel Base AChE Immobilization. Sol-gel is one of the important supports which can be used for the enzyme immobilization. The first and foremost important property of the sol-gel support is that the pore size can be adjusted according to the need. They are also chemically inert, do not show swelling in the aqueous medium, and have photochemical and thermal stability. The antibodies and the enzymes can especially be immobilized and do not allow the leakage of the enzyme in the medium. Some of the accountable demerits include denaturation of biomolecules taking place at high acidic condition and/or high alcohol concentration. 


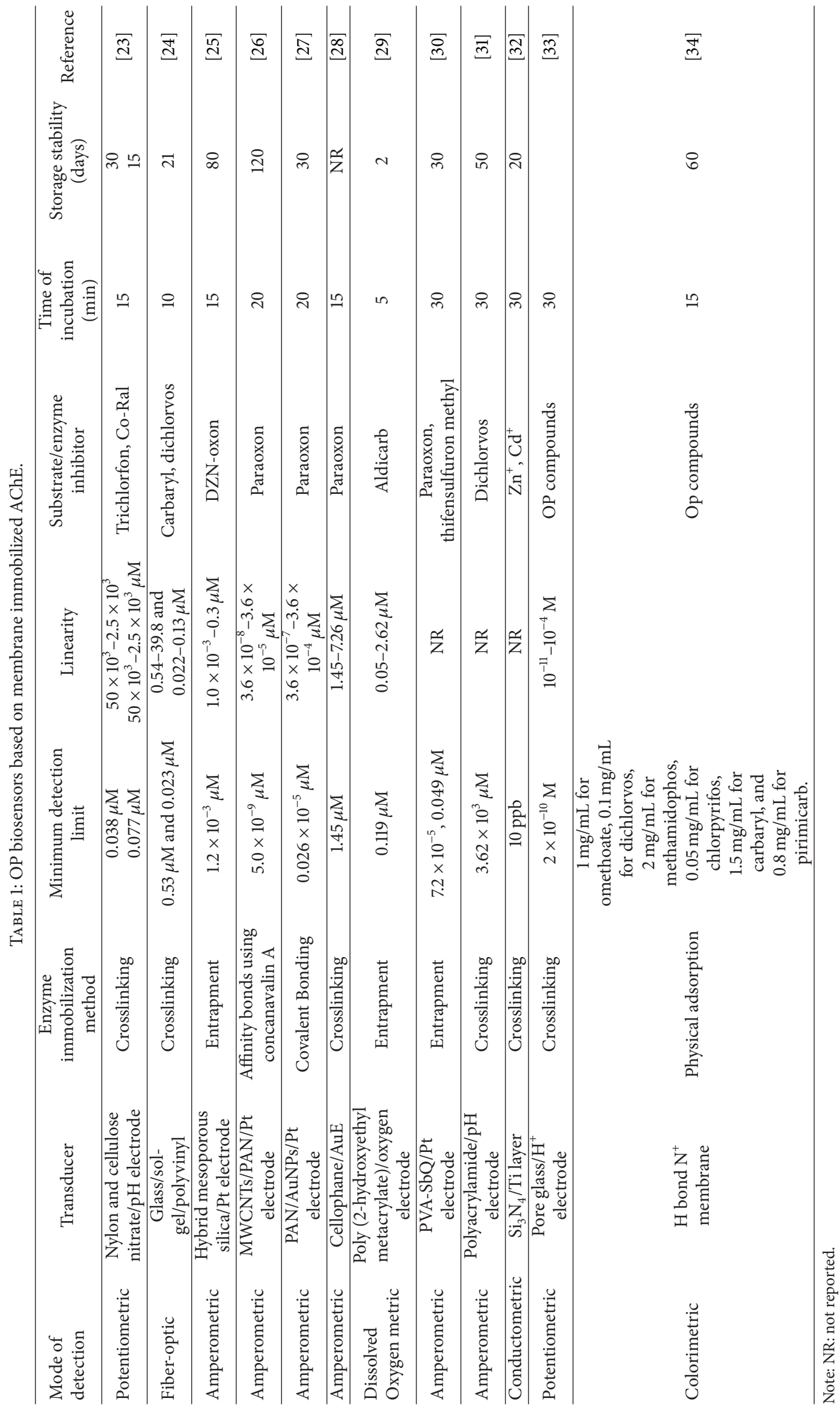




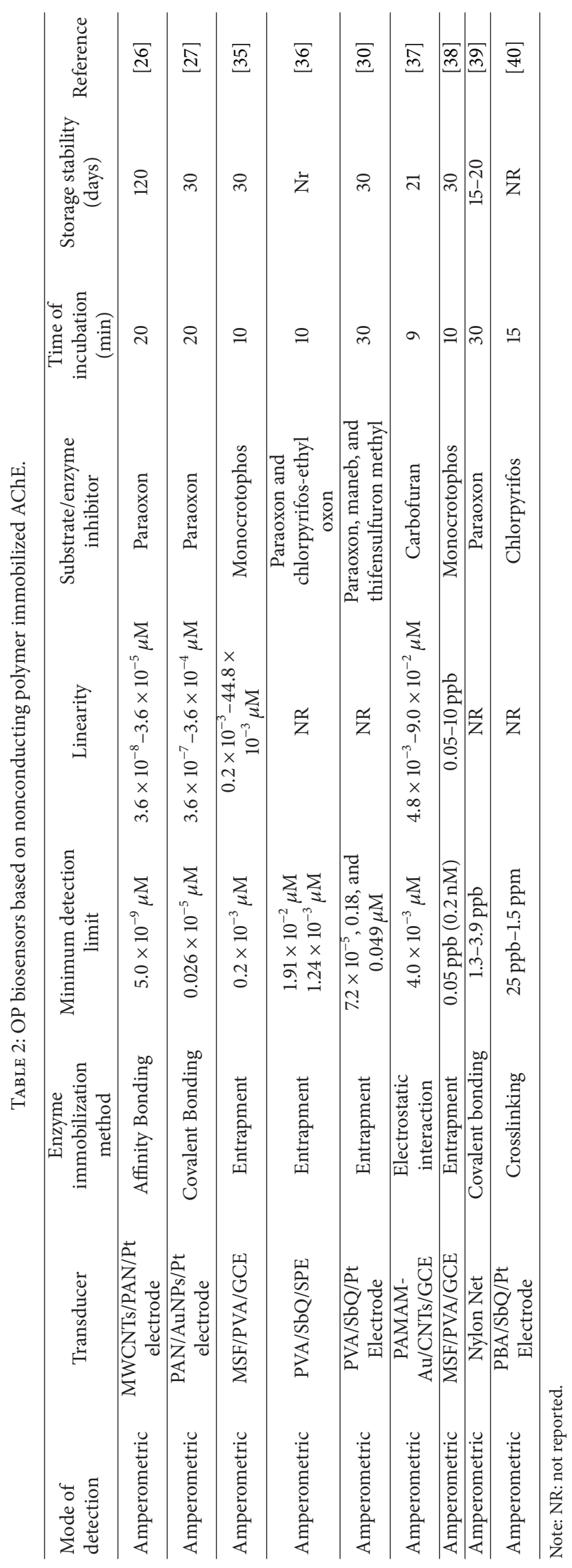




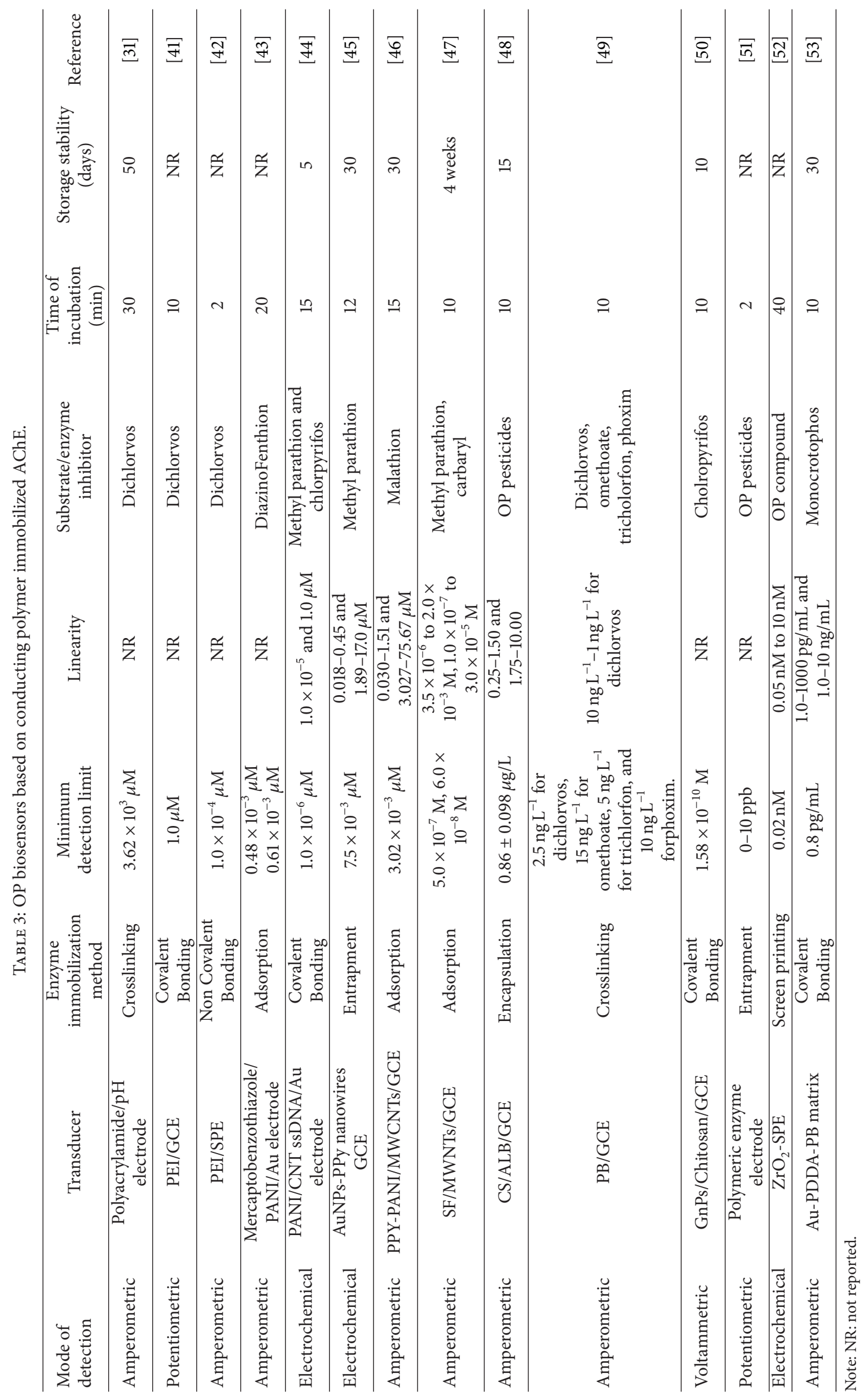


The protocols used for the sol-gel film formation are not amenable for coating the curved surfaces of substrates such as optical fibers; sufficient signals require a high level of biomolecules in sol-gel thin films but it is not possible in the case of proteins that are insoluble or aggregate in the alkoxy silane solution. Sol-gel supports used for immobilization of enzyme (Table 4) are sol-gel/TMOS [65], solgel/glass [66], silica sol-gel (SiSG) [67], TMOS/sol-gel [68, 69], chromoionophore/sol-gel [70], $\mathrm{Al}_{2} \mathrm{O}_{3}$ /sol-gel [71], solgel matrix/TCNQ [72], AuNPs-SiSG [73], alumina/sol-gel [74], sol-gel/bromothymol blue [75], $\mathrm{Zn}$ (oxide)/sol-gel [76], Si/sol-gel [77], and sol-gel/carbon electrode [78].

4.4. Screen Printing Technique. Screen-printing involves the immobilization of the biological molecules or the biological receptor in their active form. Due to the binding of the molecule in the active form, the analytical changes take place which will affect the sensitivity and the performance of the sensor developed. The necessary action must be taken for the enhancement of the selectivity, sensitivity, exposure time, and so forth. Supports used for immobilization of enzyme (Table 5) are TMOS/sol-gel/SPE [68], $\mathrm{Al}_{2} \mathrm{O}_{3} /$ solgel/SPE [71], sol-gel/TCNQ/modified SPE [72], SPE/TCNQ/ Graphite electrode [79], CoPC/SPE [80], phenylenediamine/carbon/CoPC SPE [81], graphite-epoxy/SPE [82], glutaraldehyde vapour/SPE [83], PVA-SbQ polymer/SPE [36], SWCNT-CoPC/SPE [84]. TCNQ modified graphite [85], Au electrode [86], screen printed carbon electrode [87], and PET chip SPE [88]. Screen-printing is unstable, has high crosssensitivity towards anion, and limited life span.

4.5. Quantum Dot as Immobilization Support for AChE. Quantum dots are highly luminescent photostable fluorophore. QDs are the semiconductor particles that have all the dimensions confined to the nanometre scale [124]. They have been used in biosensors as they have their great size dependent properties and are dimensionally similar with the biological molecules which are used for immobilization $[125,126]$. QDs can even be coupled with the variety of biological molecules due to which they are important in the sensing and development of the sensitive sensors. They suffer from demerits such as large size $(10$ to $30 \mathrm{~nm})$ and blinking behaviour if no emission interrupts longer periods of fluorescence. The supports which are used for the immobilization of the enzymes are (Table 6) supports used for immobilization of enzyme: CdTe QDs/AuNPs/CHIT/GCE [73], CdTe QDs/Au electrode [89], poly(allylamine hydrochloride)/CdTe QDs/glass electrode [90], Mn:ZnSe d dots [91], and CdTE QDs/Au electrode [92].

4.6. Nanomaterial Based AChE Immobilization. To improve the reliability of electrochemical based technique, researchers have been exploring the possibilities of new materials for improving the properties of transducers. Nanoparticles are proving to be a boom in the field of biosensing due to their invaluable properties such as large surface area, high conductivity, good catalytic property, and so forth. The rate of electron transfer is enhanced to a great extent. They can be synthesized in the laboratory and even their particle size can be adjusted according to the need. The carbon nanotubes are in regular use nowadays such as Single Walled Carbon Nanotubes (SWCNTs) and Multiwalled Carbon Nanotubes (MWCNTs). These carbon nanotubes are highly conductive and have large surface area. Different supports used for immobilization of enzyme (Table 7) are AuNPs$\mathrm{CaCO}_{3} / \mathrm{Au}$ electrode, Iron(Fe) NP/MWCNTs/Au electrode, FeNP/MWCNTs/indium tin oxide (ITO) electrode, AuNPs/ $\mathrm{PB} / \mathrm{GCE}$ [93], MWCNTs-Au nanocomposites/GCE [94], $\mathrm{ZrO}_{2} / \mathrm{CHIT} / \mathrm{GCE}$ [95], Au-Pt bimetallic NPs/GCE [96], AuNPs/GCE [97], AuNPs-MWCNTs/GCE [98], PB/CHIT/ GCE [99], $\mathrm{TiO}_{2}$ graphane/GCE [100], graphite-nanoplatelet CHIT composite/GCE [101], calcium carbonate-CHIT composite/GCE [102], CdS-decorated graphene nanocomposite [103], CHIT-GNPs/Au electrode [92], MWCNTs-CHIT/GCE [104], AuNPs/Au electrode [105], $\mathrm{PbO}_{2} / \mathrm{TiO}_{2} / \mathrm{Ti}$ [106], PBCHIT/GCE [107], Er-GRO/Nafion [108], SWCNT modified FGE [109], Au-PtNPs/3-aminopropyltriethoxysilanes (APTEs)/GCE [110], CNT web modified GCE [111], PANAuNPs [112], CdTe AuNPs Film [113], and SiSG-AuNPs [114].

\section{Conclusion and Future Prospects}

It is clear from the comprehensive review presented above that the AChE based OP biosensor is an important research field, with lots of applications in environmental monitoring, human health concern, and food industries. With the development of the selective biorecognition elements the high throughput screening of analyte is now possible in a reliable manner in a fraction of seconds. The large number of samples can be screened with ease and accuracy. The oxidising and reducing ability of the biorecognition element has made electrochemical biosensor the most appropriate tool for the detection purpose over the other available methods [127]. The electrochemical biosensors have the unique ability to convert the catalytic signal into the quantifiable digital signal using microfabrication electronics. Nanoparticles are proving to be most eligible in fabrication of different working electrodes. The nanomaterials can be easily synthesized in the laboratory according to the need in respect to their size and dimensions. The conductivity of nanomaterials is high due to efficient electron transfer channels developed with respect to the other supports used. The self-life of the AChE biosensor can also be increased by using nanoparticles based electrodes. A vast variety of working electrodes for the sensor development can be fabricated for the improved detection of OP compounds in different samples. The on spot detection is also an important parameter for the biosensors which is possible due to the screen-printing technology. Screen-printed biosensors can be fabricated in miniaturization form for on-site rapid monitoring of the analyte. But till now the commercialization of the biosensors has not been possible due to the high cost of the enzyme in the market. Less work has been done on the validation of the enzymatic biosensors with respect to the real samples. Many interfering compounds are present in 


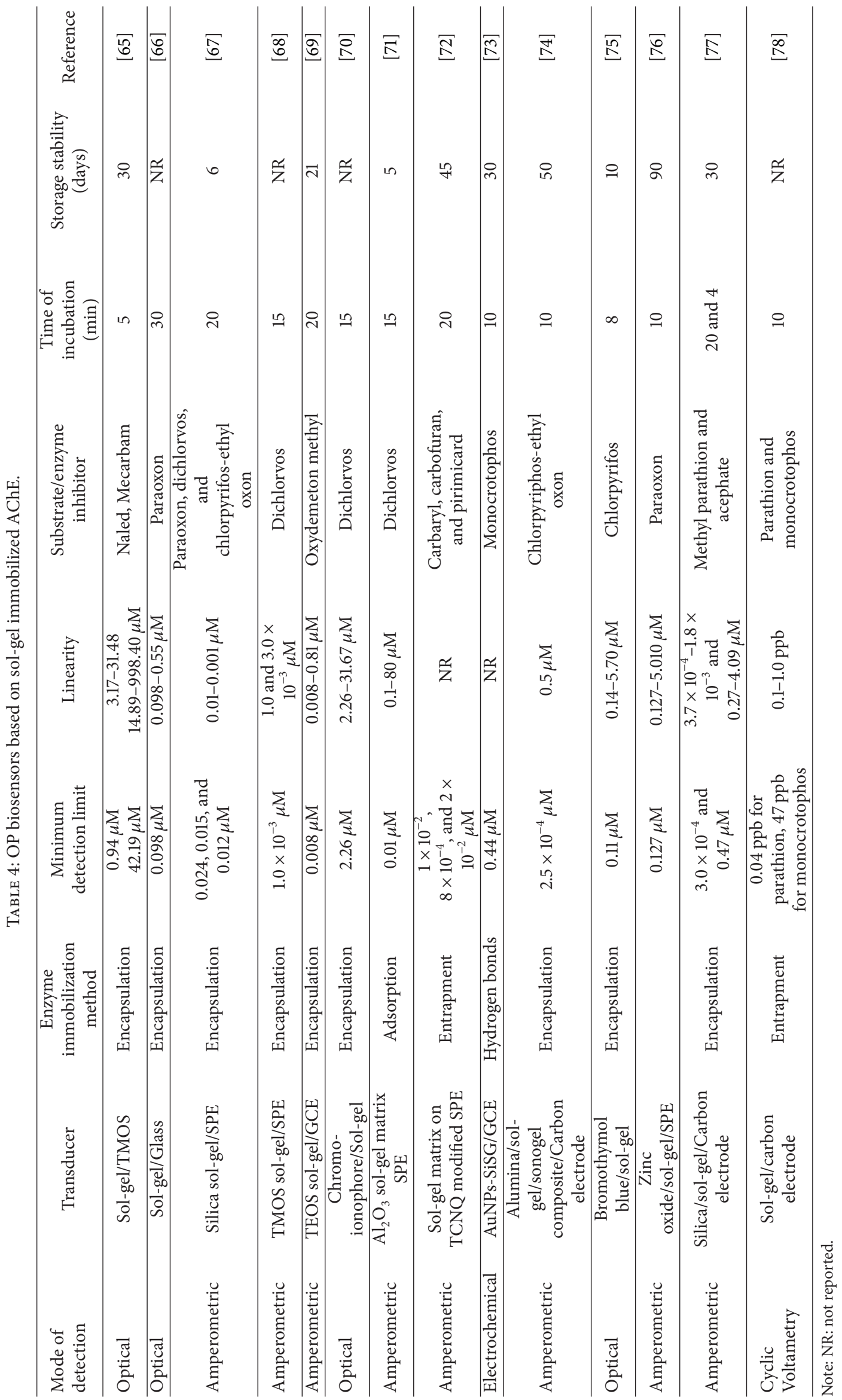




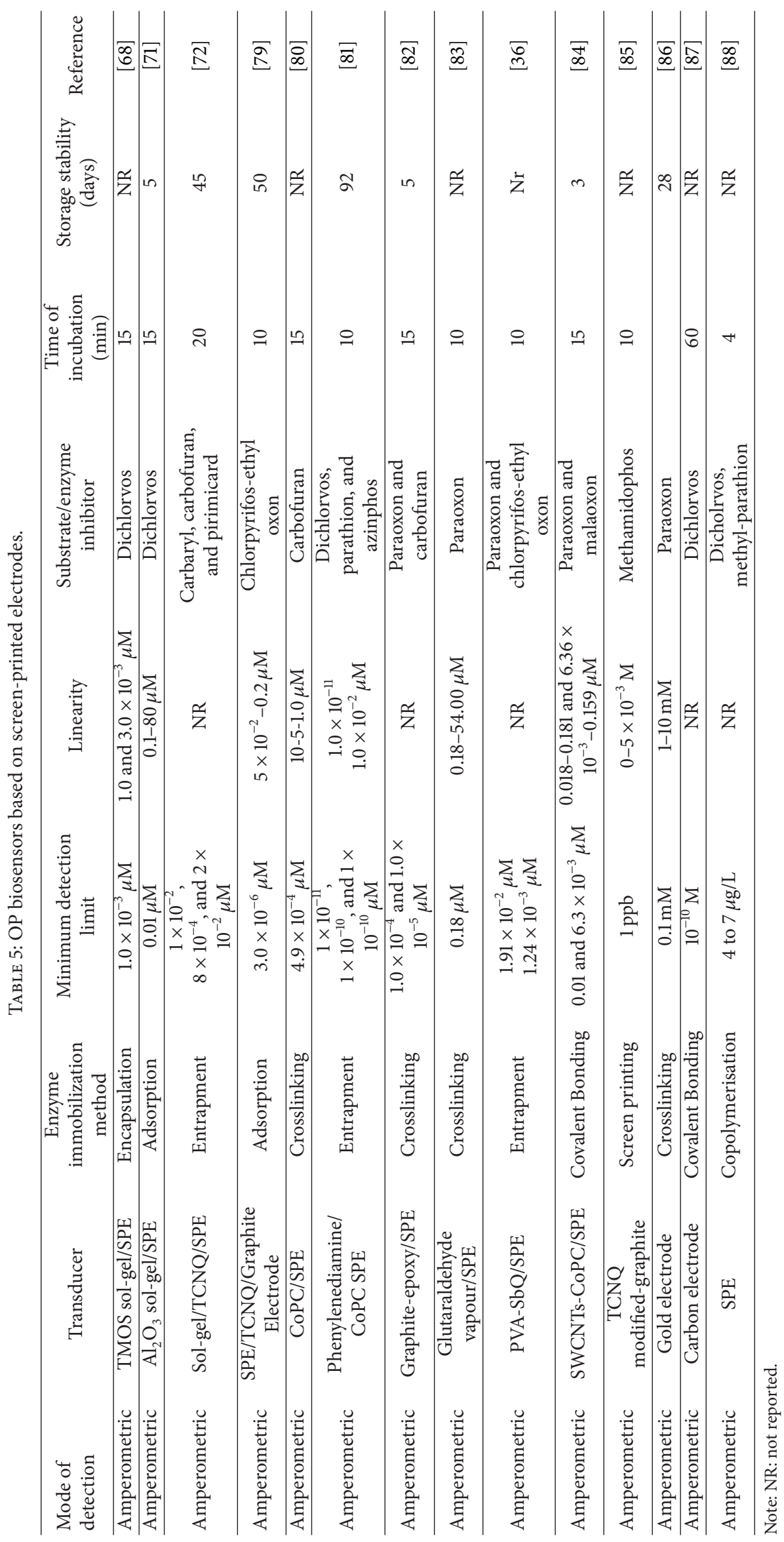




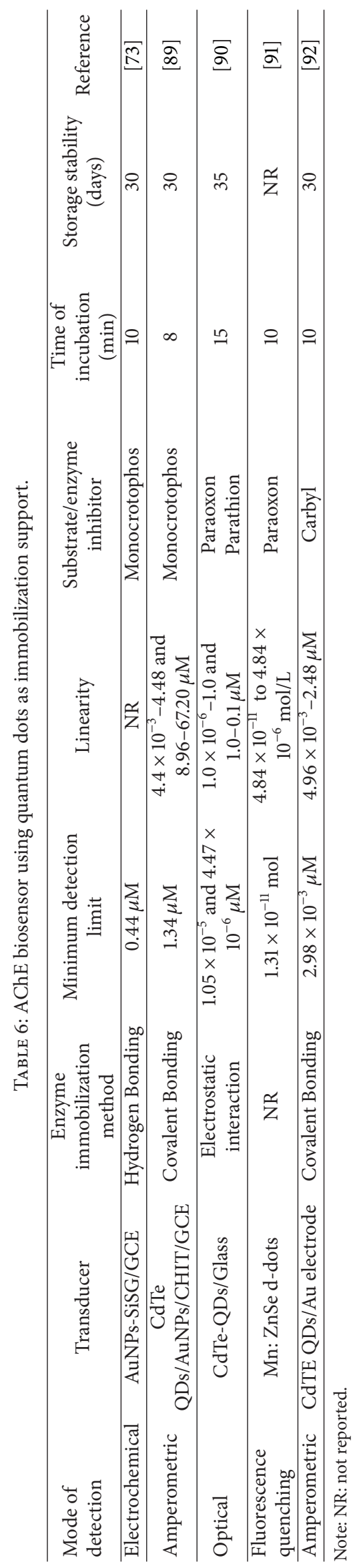




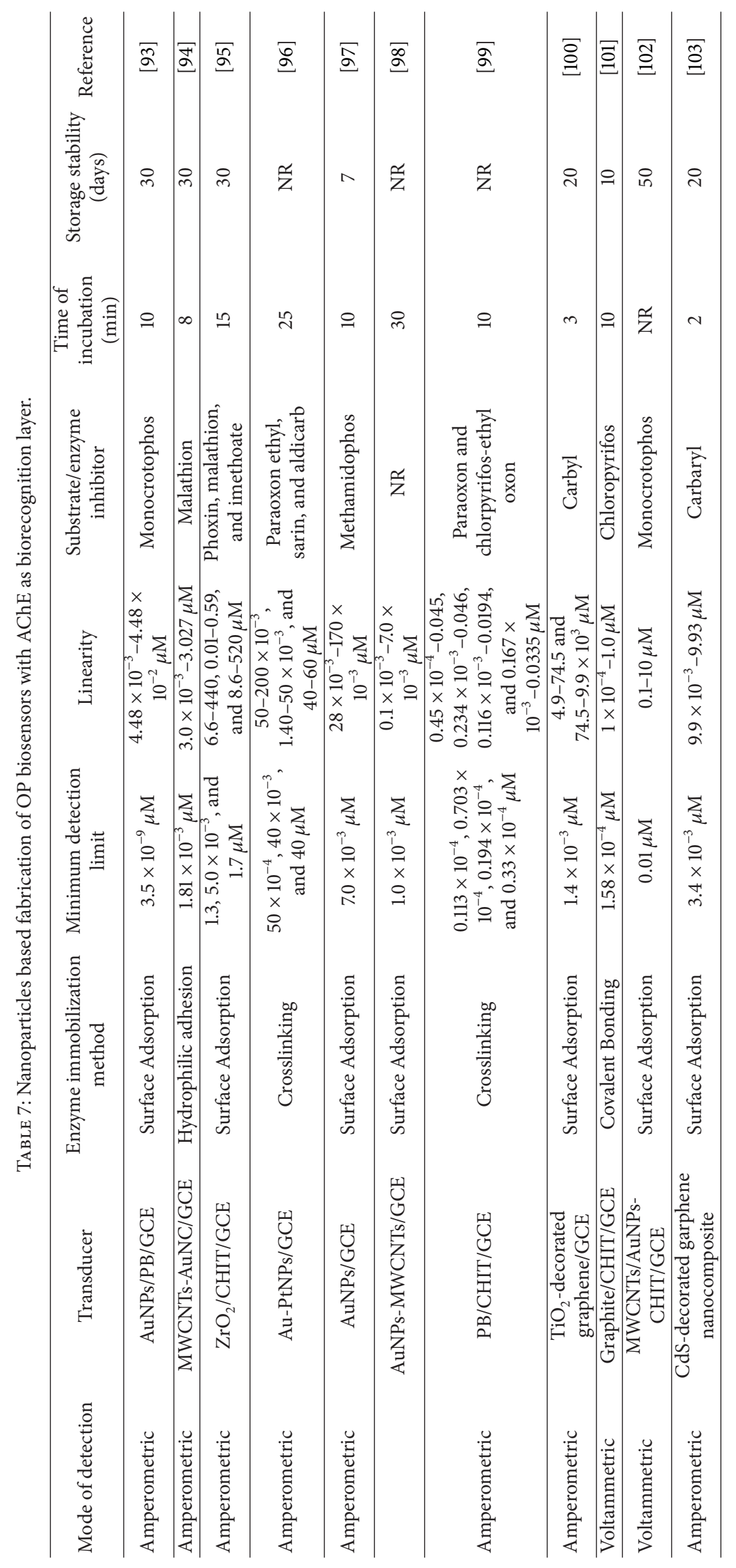




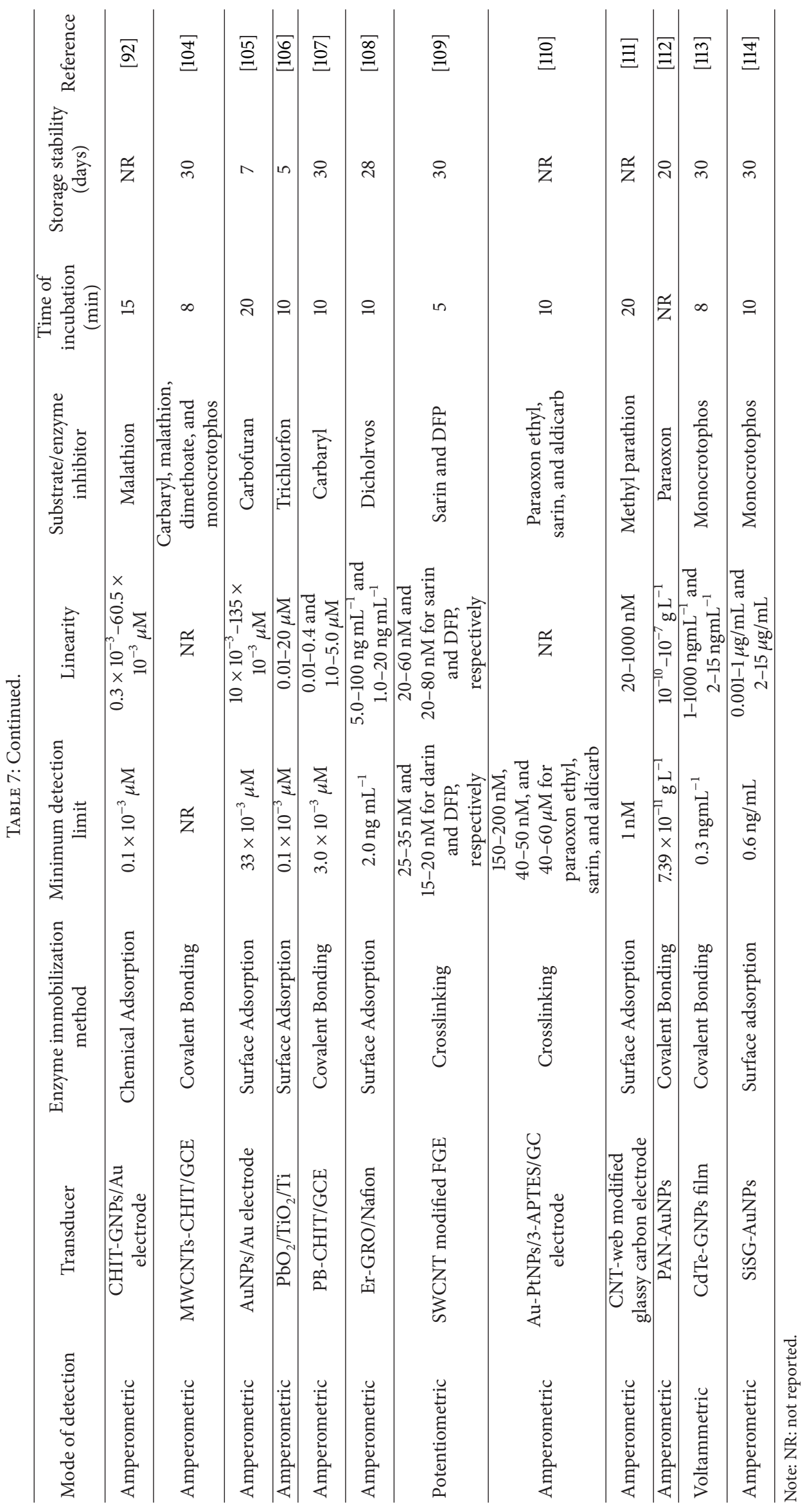


the sample and can hamper the sensitivity of the biosensor. The biosensors must be validated to explore the effect of interfering compounds on the pesticide detection.

\section{Conflict of Interests}

The author(s) declare(s) that there is no conflict of interests regarding the publication of this paper.

\section{Acknowledgments}

The authors thank the financial support from the Department of Science \& Technology, New Delhi, for providing INSPIRE fellowship as JRF-P (IF110655) to carry out research work. Also they are thankful to Department of Bio \& Nanotechnology, GJUS\&T, Hisar and Biosensors \& Diagnostics Laboratory, Centre for Biotechnology, MDU, Rohtak.

\section{References}

[1] A. Mulchandani, W. Chen, P. Mulchandani, J. Wang, and K. R. Rogers, "Biosensors for direct determination of organophosphate pesticides," Biosensors and Bioelectronics, vol. 16, no. 4-5, pp. 225-230, 2001.

[2] P. Moris, I. Alexandre, M. Roger, and J. Remacle, "Chemiluminescence assays of organophosphorus and carbamate pesticides," Analytica Chimica Acta, vol. 302, no. 1, pp. 53-59, 1995.

[3] FAO, "Agriculture: towards 2010 document," in Proceedings of the C 93/94 Document of 27th Session of the FAO Conference, Rome, Italy, 1993.

[4] L. Aspelin, Pesticide Industry Sales and Usage, 1992 and 1993 Market Estimates, U.S. Environmental Protection Agency, Washington, DC, USA, 1994.

[5] C. Tran-Minh, P. C. Pandey, and S. Kumaran, "Studies on acetylcholine sensor and its analytical application based on the inhibition of cholinesterase," Biosensors and Bioelectronics, vol. 5, no. 6, pp. 461-471, 1990.

[6] C. Cremisini, S. Di Sario, J. Mela, R. Pilloton, and G. Palleschi, "Evaluation of the use of free and immobilised acetylcholinesterase for paraoxon detection with an amperometric choline oxidase based biosensor," Analytica Chimica Acta, vol. 311, no. 3, pp. 273-280, 1995.

[7] H. Eyer, D. P. J. Moran, and K. K. Rajah, "Fats in food products," Food and Science Technology, vol. 28, p. 162, 1995.

[8] K. Steenland, "Chronic neurological effects of organophosphate pesticides," British Medical Journal, vol. 312, no. 7042, pp. 13121313, 1996.

[9] G. A. Jamal, "Neurological syndromes of organophosphorus compounds," Adverse Drug Reactions and Toxicological Reviews, vol. 16, no. 3, pp. 133-170, 1997.

[10] D. E. Ray, "Chronic effects of low level exposure to anticholinesterases-a mechanistic review," Toxicology Letters, vol. 102-103, pp. 527-533, 1998.

[11] W. J. Donarski, D. P. Dumas, D. P. Heitmeyer, V. E. Lewis, and F. M. Raushel, "Structure-activity relationships in the hydrolysis of substrates by the phosphotriesterase from Pseudomonas diminuta," Biochemistry, vol. 28, no. 11, pp. 4650-4655, 1989.

[12] S. Chapalamadugu and G. R. Chaudhry, "Microbiological and biotechnological aspects of metabolism of carbamates and organophosphates," Critical Reviews in Biotechnology, vol. 12, no. 5-6, pp. 357-389, 1992.

[13] T. S. S. Dikshith, "Pesticides," in Toxicology of Pesticides in Animals, T. S. S. Dikshith, Ed., pp. 1-39, CRC Press, Boston, Mass, USA, 1991.

[14] E. Jover and J. Maria Bayona, "Trace level determination of organochlorine, organophosphorus and pyrethroid pesticides in lanolin using gel permeation chromatography followed by dual gas chromatography and gas chromatography-negative chemical ionization mass spectrometric confirmation," Journal of Chromatography A, vol. 950, no. 1-2, pp. 213-220, 2002.

[15] J. Zhang, A. Luo, P. Liu, S. Wei, G. Wang, and S. Wei, "Detection of organophosphorus pesticides using potentiometric enzymatic membrane biosensor based on methylcellulose immobilization," Analytical Sciences, vol. 25, no. 4, pp. 511-515, 2009.

[16] W.-J. Lü, Y.-L. Chen, J.-H. Zhu, and X.-G. Chen, “The combination of flow injection with electrophoresis using capillaries and chips," Electrophoresis, vol. 30, no. 1, pp. 83-91, 2009.

[17] G. L. Ellman, K. D. Courtney, V. Andres Jr., and R. M. Featherstone, "A new and rapid colorimetric determination of acetylcholinesterase activity," Biochemical Pharmacology, vol. 7, no. 2, pp. 88-95, 1961.

[18] G. R. van der Hoff and P. van Zoonen, "Trace analysis of pesticides by gas chromatography," Journal of Chromatography $A$, vol. 843, no. 1-2, pp. 301-322, 1999.

[19] F. Hernández, J. V. Sancho, O. Pozo, A. Lara, and E. Pitarch, "Rapid direct determination of pesticides and metabolites in environmental water samples at sub- $\mu \mathrm{g} / \mathrm{l}$ level by on-line solidphase extraction-liquid chromatography-electrospray tandem mass spectrometry," Journal of Chromatography A, vol. 939, no. 1-2, pp. 1-11, 2001.

[20] J. Sherma, "Thin-layer chromatography of pesticides-a review of applications for 2002-2004," Acta Chromatographica, no. 15, pp. 5-30, 2005.

[21] T. D. Sutherland, I. Horne, R. J. Russell, and J. G. Oakeshott, "Gene cloning and molecular characterization of a two-enzyme system catalyzing the oxidative detoxification of $\beta$-endosulfan," Applied and Environmental Microbiology, vol. 68, no. 12, pp. 6237-6245, 2002.

[22] H. Mitobe, T. Ibaraki, A. Tanabe, K. Kawata, and A. Yasuhara, "High performance liquid chromatographic determination of pesticides in soluble phase and suspended phase in river water," Toxicological and Environmental Chemistry, vol. 81, no. 3-4, pp. 97-110, 2001.

[23] A. N. Ivanov, G. A. Evtugyn, R. E. Gyurcsányi, K. Tóth, and H. C. Budnikov, "Comparative investigation of electrochemical cholinesterase biosensors for pesticide determination," Analytica Chimica Acta, vol. 404, no. 1, pp. 55-65, 2000.

[24] V. G. Andreou and Y. D. Clonis, "A portable fiber-optic pesticide biosensor based on immobilized cholinesterase and sol-gel entrapped bromcresol purple for in-field use," Biosensors and Bioelectronics, vol. 17, no. 1-2, pp. 61-69, 2002.

[25] T. Shimomura, T. Itoh, T. Sumiya, F. Mizukami, and M. Ono, "Amperometric biosensor based on enzymes immobilized in hybrid mesoporous membranes for the determination of acetylcholine," Enzyme and Microbial Technology, vol. 45, no. 67, pp. 443-448, 2009.

[26] Y. Ivanov, I. Marinov, K. Gabrovska, N. Dimcheva, and T. Godjevargova, "Amperometric biosensor based on a site-specific immobilization of acetylcholinesterase via affinity bonds on 
a nanostructured polymer membrane with integrated multiwall carbon nanotubes," Journal of Molecular Catalysis B, vol. 63, no. 3-4, pp. 141-148, 2010.

[27] I. Marinov, Y. Ivanov, K. Gabrovska, and T. Godjevargova, "Amperometric acetylthiocholine sensor based on acetylcholinesterase immobilized on nanostructured polymer membrane containing gold nanoparticles," Journal of Molecular Catalysis B, vol. 62, no. 1, pp. 66-74, 2010.

[28] K. Rekha and B. N. Murthy, "Studies on the immobilisation of acetylcholine esterase enzyme for biosensor applications," Food and Agricultural Immunology, vol. 19, no. 4, pp. 273-281, 2008.

[29] F. N. Kok, F. Bozoglu, and V. Hasirci, "Construction of an acetylcholinesterase-choline oxidase biosensor for aldicarb determination," Biosensors and Bioelectronics, vol. 17, no. 6-7, pp. 531-539, 2002.

[30] J.-L. Marty, N. Mionetto, T. Noguer, F. Ortega, and C. Roux, "Enzyme sensors for the detection of pesticides," Biosensors and Bioelectronics, vol. 8, no. 6, pp. 273-280, 1993.

[31] K. Stein and G. Schwedt, "Comparison of immobilization methods for the development of an acetylcholinesterase biosensor," Analytica Chimica Acta, vol. 272, no. 1, pp. 73-81, 1993.

[32] C. Chouteau, S. Dzyadevych, C. Durrieu, and J.-M. Chovelon, "A bi-enzymatic whole cell conductometric biosensor for heavy metal ions and pesticides detection in water samples," Biosensors and Bioelectronics, vol. 21, no. 2, pp. 273-281, 2005.

[33] H.-S. Lee, Y. A. Kim, Y. A. Cho, and Y. T. Lee, "Oxidation of organophosphorus pesticides for the sensitive detection by a cholinesterase-based biosensor," Chemosphere, vol. 46, no. 4, pp. 571-576, 2002.

[34] X. Guo, X. Zhang, Q. Cai, T. Shen, and S. Zhu, "Developing a novel sensitive visual screening card for rapid detection of pesticide residues in food," Food Control, vol. 30, pp. 15-23, 2013.

[35] S. Wu, L. Zhang, L. Qi et al., "Ultra-sensitive biosensor based on mesocellular silica foam for organophosphorous pesticide detection," Biosensors and Bioelectronics, vol. 26, no. 6, pp. 2864-2869, 2011.

[36] S. Andreescu, T. Noguer, V. Magearu, and J.-L. Marty, "Screenprinted electrode based on ache for the detection of pesticides in presence of organic solvents," Talanta, vol. 57, no. 1, pp. 169$176,2002$.

[37] Y. Qu, Q. Sun, F. Xiao, G. Shi, and L. Jin, "Layer-by-Layer selfassembled acetylcholinesterase/PAMAM-Au on CNTs modified electrode for sensing pesticides," Bioelectrochemistry, vol. 77, no. 2, pp. 139-144, 2010.

[38] S. Wu, L. Zhang, L. Qi et al., "Ultra-sensitive biosensor based on mesocellular silica foam for organophosphorous pesticide detection," Biosensors and Bioelectronics, vol. 26, no. 6, pp. 2864-2869, 2011.

[39] C. Cremisini, S. Di Sario, J. Mela, R. Pilloton, and G. Palleschi, "Evaluation of the use of free and immobilised acetylcholinesterase for paraoxon detection with an amperometric choline oxidase based biosensor," Analytica Chimica Acta, vol. 311, no. 3, pp. 273-280, 1995.

[40] G. Jeanty, C. Ghommidh, and J. L. Marty, "Automated detection of chlorpyrifos and its metabolites by a continuous flow systembased enzyme sensor," Analytica Chimica Acta, vol. 436, no. 1, pp. 119-128, 2001.

[41] D. M. Ivnitskii and J. Rishpon, "A potentiometric biosensor for pesticides based on the thiocholine hexacyanoferrate (III) reaction," Biosensors and Bioelectronics, vol. 9, no. 8, pp. 569$576,1994$.
[42] A. Vakurov, C. E. Simpson, C. L. Daly, T. D. Gibson, and P. A. Millner, "Acetylcholinesterase-based biosensor electrodes for organophosphate pesticide detection: I. Modification of carbon surface for immobilization of acetylcholinesterase," Biosensors and Bioelectronics, vol. 20, no. 6, pp. 1118-1125, 2004.

[43] V. S. Somerset, M. J. Klink, P. G. L. Baker, and E. I. Iwuoha, "Acetylcholinesterase-polyaniline biosensor investigation of organophosphate pesticides in selected organic solvents," Journal of Environmental Science and Health B, vol. 42, no. 3, pp. 297-304, 2007.

[44] S. Viswanathan, H. Radecka, and J. Radecki, "Electrochemical biosensor for pesticides based on acetylcholinesterase immobilized on polyaniline deposited on vertically assembled carbon nanotubes wrapped with ssDNA," Biosensors and Bioelectronics, vol. 24, no. 9, pp. 2772-2777, 2009.

[45] J. Gong, L. Wang, and L. Zhang, "Electrochemical biosensing of methyl parathion pesticide based on acetylcholinesterase immobilized onto Au-polypyrrole interlaced network-like nanocomposite," Biosensors and Bioelectronics, vol. 24, no. 7, pp. 2285-2288, 2009.

[46] D. Du, X. Ye, J. Cai, J. Liu, and A. Zhang, "Acetylcholinesterase biosensor design based on carbon nanotube-encapsulated polypyrrole and polyaniline copolymer for amperometric detection of organophosphates," Biosensors and Bioelectronics, vol. 25, no. 11, pp. 2503-2508, 2010.

[47] R. Xue, T.-F. Kang, L.-P. Lu, and S.-Y. Cheng, "Immobilization of acetylcholinesterase via biocompatible interface of silk fibroin for detection of organophosphate and carbamate pesticides," Applied Surface Science, vol. 258, no. 16, pp. 6040-6045, 2012.

[48] H. Guan, F. Zhang, J. Yu, and D. Chi, "The novel acetylcholinesterase biosensors based on liposome bioreactorschitosan nanocomposite film for detection of organophosphates pesticides," Food Research International, vol. 49, pp. 15-21, 2012.

[49] X. Sun and X. Wang, "Acetylcholinesterase biosensor based on prussian blue-modified electrode for detecting organophosphorous pesticides," Biosensors and Bioelectronics, vol. 25, no. 12, pp. 2611-2614, 2010.

[50] A. C. Ion, I. Ion, A. Culetu et al., "Acetylcholinesterase voltammetric biosensors based on carbon nanostructure-chitosan composite material for organophosphate pesticides," Materials Science and Engineering C, vol. 30, no. 6, pp. 817-821, 2010.

[51] K. Dutta, D. Bhattacharyay, A. Mukherjee, S. J. Setford, A. P. F. Turner, and P. Sarkar, "Detection of pesticide by polymeric enzyme electrodes," Ecotoxicology and Environmental Safety, vol. 69, no. 3, pp. 556-561, 2008.

[52] D. Du, A. Chen, Y. Xie, A. Zhang, and Y. Lin, "Nanoparticlebased immunosensor with apoferritin templated metallic phosphate label for quantification of phosphorylated acetylcholinesterase," Biosensors and Bioelectronics, vol. 26, no. 9, pp. 3857-3863, 2011.

[53] S. Wu, X. Lan, W. Zhao et al., "Controlled immobilization of acetylcholinesterase on improved hydrophobic gold nanoparticle/Prussian blue modified surface for ultra-trace organophosphate pesticide detection," Biosensors and Bioelectronics, vol. 27, no. 1, pp. 82-87, 2011.

[54] W. N. Aldridge and A. N. Davison, "The mechanism of inhibition of cholinesterase by organophosphorus compounds," Biochemical Journal, vol. 55, pp. 763-766, 1953.

[55] Y. Boublik, P. Saint-Aguet, A. Lougarre et al., "Acetylcholinesterase engineering for detection of insecticide residues," Protein Engineering, vol. 15, no. 1, pp. 43-50, 2002. 
[56] G. L. Turdean, I. C. Popescu, L. Oniciu, and D. R. Thevenot, "Sensitive detection of organophosphorus pesticides using a needle type amperometric acetylcholinesterase-based bioelectrode. Thiocholine electrochemistry and immobilised enzyme inhibition," Journal of Enzyme Inhibition and Medicinal Chemistry, vol. 17, no. 2, pp. 107-115, 2002.

[57] I. Palchetti, A. Cagnini, M. Del Carlo, C. Coppi, M. Mascini, and A. P. F. Turner, "Determination of anticholinesterase pesticides in real samples using a disposable biosensor," Analytica Chimica Acta, vol. 337, no. 3, pp. 315-321, 1997.

[58] P. Skládal, G. S. Nunes, H. Yamanaka, and M. L. Ribeiro, "Detection of Carbamate Pesticides in Vegetable Samples Using Cholinesterase-Based Biosensors," Electroanalysis, vol. 9, no. 14, pp. 1083-1087, 1997.

[59] J. Wang, "Electrochemical glucose biosensors," Chemical Reviews, vol. 108, no. 2, pp. 814-825, 2008.

[60] C. F. de Jong, R. J. E. Derks, B. Bruyneel, W. Niessen, and $\mathrm{H}$. Irth, "High-performance liquid chromatography-mass spectrometry-based acetylcholinesterase assay for the screening of inhibitors in natural extracts," Journal of Chromatography A, vol. 1112, no. 1-2, pp. 303-310, 2006.

[61] A. A. Weinbroum, "Pathophysiological and clinical aspects of combat anticholinesterase poisoning," British Medical Bulletin, vol. 72, pp. 119-133, 2004.

[62] C. Pope, S. Karanth, and J. Liu, "Pharmacology and toxicology of cholinesterase inhibitors: uses and misuses of a common mechanism of action," Environmental Toxicology and Pharmacology, vol. 19, no. 3, pp. 433-446, 2005.

[63] N. Jha and S. Ramaprabhu, "Development of MWNT based disposable biosensor on glassy Carbon electrode for the detection of organophosphorus nerve agents," Journal of Nanoscience and Nanotechnology, vol. 9, no. 9, pp. 5676-5680, 2009.

[64] S. V. Dzydevich, A. A. Shulga, A. P. Soldatkin, A. M. N. Hendji, N. J. Renault, and C. Martelet, "Conductometric biosensors based on cholinesterases for sensitive detection of pesticides," Electroanalysis, vol. 6, pp. 752-758, 1994.

[65] A. Navas Díaz and M. C. Ramos Peinado, "Sol-gel cholinesterase biosensor for organophosphorus pesticide fluorimetric analysis," Sensors and Actuators B, vol. 39, no. 1-3, pp. 426-431, 1997.

[66] R.-A. Doong and H.-C. Tsai, "Immobilization and characterization of sol-gel-encapsulated acetylcholinesterase fiber-optic biosensor," Analytica Chimica Acta, vol. 434, no. 2, pp. 239-246, 2001.

[67] S. Andreescu, L. Barthelmebs, and J.-L. Marty, "Immobilization of acetylcholinesterase on screen-printed electrodes: comparative study between three immobilization methods and applications to the detection of organophosphorus insecticides," Analytica Chimica Acta, vol. 464, no. 2, pp. 171-180, 2002.

[68] S. Sotiropoulou and N. A. Chaniotakis, "Tuning the solgel microenvironment for acetylcholinesterase encapsulation," Biomaterials, vol. 26, no. 33, pp. 6771-6779, 2005.

[69] K. Anitha, S. V. Mohan, and S. J. Reddy, "Development of acetylcholinesterase silica sol-gel immobilized biosensor-an application towards oxydemeton methyl detection," Biosensors \& bioelectronics, vol. 20, no. 4, pp. 848-856, 2004.

[70] F. C. M. Wong, M. Ahmad, L. Y. Heng, and L. B. Peng, "An optical biosensor for dichlovos using stacked sol-gel films containing acetylcholinesterase and a lipophilic chromoionophore," Talanta, vol. 69, no. 4, pp. 888-893, 2006.

[71] M. Shi, J. Xu, S. Zhang, B. Liu, and J. Kong, "A mediatorfree screen-printed amperometric biosensor for screening of organophosphorus pesticides with flow-injection analysis (FIA) system," Talanta, vol. 68, no. 4, pp. 1089-1095, 2006.

[72] B. Bucur, D. Fournier, A. Danet, and J.-L. Marty, "Biosensors based on highly sensitive acetylcholinesterases for enhanced carbamate insecticides detection," Analytica Chimica Acta, vol. 562, no. 1, pp. 115-121, 2006.

[73] D. Du, S. Chen, J. Cai, and A. Zhang, "Electrochemical pesticide sensitivity test using acetylcholinesterase biosensor based on colloidal gold nanoparticle modified sol-gel interface," Talanta, vol. 74, no. 4, pp. 766-772, 2008.

[74] H. Zejli, J. L. Hidalgo-Hidalgo de Cisneros, I. NaranjoRodriguez, B. Liu, K. R. Temsamani, and J.-L. Marty, "Alumina sol-gel/sonogel-carbon electrode based on acetylcholinesterase for detection of organophosphorus pesticides," Talanta, vol. 77, no. 1, pp. 217-221, 2008.

[75] B. Kuswandi, C. I. Fikriyah, and A. A. Gani, "An optical fiber biosensor for chlorpyrifos using a single sol-gel film containing acetylcholinesterase and bromothymol blue," Talanta, vol. 74, no. 4, pp. 613-618, 2008.

[76] R. Sinha, M. Ganesana, S. Andreescu, and L. Stanciu, "AChE biosensor based on zinc oxide sol-gel for the detection of pesticides," Analytica Chimica Acta, vol. 661, no. 2, pp. 195-199, 2010.

[77] P. Raghu, B. E. Kumara Swamy, T. Madhusudana Reddy, B. N. Chandrashekar, and K. Reddaiah, "Sol-gel immobilized biosensor for the detection of organophosphorous pesticides: a voltammetric method," Bioelectrochemistry, vol. 83, no. 1, pp. 19-24, 2012.

[78] P. Raghu, T. Madhusudana Reddy, B. E. Kumara Swamy, B. N. Chandrashekar, K. Reddaiah, and M. Sreedhar, "Development of AChE biosensor for the determination of methyl parathion and monocrotophos in water and fruit samples: a cyclic voltammetric study," Journal of Electroanalytical Chemistry, vol. 665, pp. 76-82, 2012.

[79] C. Bonnet, S. Andreescu, and J.-L. Marty, "Adsorption: an easy and efficient immobilisation of acetylcholinesterase on screenprinted electrodes," Analytica Chimica Acta, vol. 481, no. 2, pp. 209-211, 2003.

[80] S. Laschi, D. Ogończyk, I. Palchetti, and M. Mascini, "Evaluation of pesticide-induced acetylcholinesterase inhibition by means of disposable carbon-modified electrochemical biosensors," Enzyme and Microbial Technology, vol. 40, no. 3, pp. 485489, 2007.

[81] K. A. Law and S. P. J. Higson, "Sonochemically fabricated acetylcholinesterase micro-electrode arrays within a flow injection analyser for the determination of organophosphate pesticides," Biosensors and Bioelectronics, vol. 20, no. 10, pp. 1914-1924, 2005.

[82] M. Albareda-Sirvent, A. Merkoçi, and S. Alegret, "Pesticide determination in tap water and juice samples using disposable amperometric biosensors made using thick-film technology," Analytica Chimica Acta, vol. 442, no. 1, pp. 35-44, 2001.

[83] Y.-G. Li, Y.-X. Zhou, J.-L. Feng, Z.-H. Jiang, and L.-R. $\mathrm{Ma}$, "Immobilization of enzyme on screen-printed electrode by exposure to glutaraldehyde vapour for the construction of amperometric acetylcholinesterase electrodes," Analytica Chimica Acta, vol. 382, no. 3, pp. 277-282, 1999.

[84] A. N. Ivanov, R. R. Younusov, G. A. Evtugyn, F. Arduini, D. Moscone, and G. Palleschi, "Acetylcholinesterase biosensor based on single-walled carbon nanotubes-co phtalocyanine for organophosphorus pesticides detection," Talanta, vol. 85, no. 1, pp. 216-221, 2011. 
[85] P. R. B. de Oliveira Marques, G. S. Nunes, T. C. R. dos Santos, S. Andreescu, and J.-L. Marty, "Comparative investigation between acetylcholinesterase obtained from commercial sources and genetically modified Drosophila melanogaster: application in amperometric biosensors for methamidophos pesticide detection," Biosensors \& bioelectronics, vol. 20, no. 4, pp. 825-832, 2004.

[86] J. Wang, R. Krause, K. Block, M. Musameh, A. Mulchandani, and M. J. Schöning, "Flow injection amperometric detection of OP nerve agents based on an organophosphorus-hydrolase biosensor detector," Biosensors and Bioelectronics, vol. 18, no. 23, pp. 255-260, 2002.

[87] A. Vakurov, C. E. Simpson, C. L. Daly, T. D. Gibson, and P. A. Millner, "Acetylcholinesterase-based biosensor electrodes for organophosphate pesticide detection: I. Modification of carbon surface for immobilization of acetylcholinesterase," Biosensors and Bioelectronics, vol. 20, no. 6, pp. 1118-1125, 2004.

[88] J. Dou, F. Fan, A. Ding et al., "A screen-printed, amperometric biosensor for the determination of organophosphorus pesticides in water samples," Journal of Environmental Sciences, vol. 24, no. 5, pp. 956-962, 2012.

[89] D. Du, S. Chen, D. Song, H. Li, and X. Chen, "Development of acetylcholinesterase biosensor based on CdTe quantum dots/gold nanoparticles modified chitosan microspheres interface," Biosensors and Bioelectronics, vol. 24, no. 3, pp. 475-479, 2008.

[90] Z. Zheng, Y. Zhou, X. Li, S. Liu, and Z. Tang, "Highly-sensitive organophosphorous pesticide biosensors based on nanostructured films of acetylcholinesterase and CdTe quantum dots," Biosensors and Bioelectronics, vol. 26, no. 6, pp. 3081-3085, 2011.

[91] X. Gao, G. Tang, and X. Su, "Optical detection of organophosphorus compounds based on Mn-doped ZnSe d-dot enzymatic catalytic sensor," Biosensors and Bioelectronics, vol. 36, pp. 7580, 2012.

[92] D. Du, J. Ding, Y. Tao, and X. Chen, "Application of chemisorption/desorption process of thiocholine for pesticide detection based on acetylcholinesterase biosensor," Sensors and Actuators B, vol. 134, no. 2, pp. 908-912, 2008.

[93] S. Wu, X. Lan, W. Zhao et al., "Controlled immobilization of acetylcholinesterase on improved hydrophobic gold nanoparticle/Prussian blue modified surface for ultra-trace organophosphate pesticide detection," Biosensors and Bioelectronics, vol. 27, no. 1, pp. 82-87, 2011.

[94] D. Du, M. Wang, J. Cai, Y. Qin, and A. Zhang, “One-step synthesis of multiwalled carbon nanotubes-gold nanocomposites for fabricating amperometric acetylcholinesterase biosensor," Sensors and Actuators B, vol. 143, no. 2, pp. 524-529, 2010.

[95] Y. Yang, M. Guo, M. Yang, Z. Wang, G. Shen, and R. Yu, "Determination of pesticides in vegetable samples using an acetylcholinesterase biosensor based on nanoparticles $\mathrm{ZrO} 2 /$ chitosan composite film," International Journal of Environmental Analytical Chemistry, vol. 85, no. 3, pp. 163-175, 2005.

[96] S. Upadhyay, G. R. Rao, M. K. Sharma, B. K. Bhattacharya, V. K. Rao, and R. Vijayaraghavan, "Immobilization of acetylcholineesterase-choline oxidase on a gold-platinum bimetallic nanoparticles modified glassy carbon electrode for the sensitive detection of organophosphate pesticides, carbamates and nerve agents," Biosensors and Bioelectronics, vol. 25, no. 4, pp. 832-838, 2009.

[97] Y. R. Li, Z. Y. Gan, Y. F. Li et al., "Immobilization of acetylcholinesterase on one-dimensional gold nanoparticles for detection of organophosphorous insecticides," Science China Chemistry, vol. 53, no. 4, pp. 820-825, 2010.

[98] N. Jha and S. Ramaprabhu, "Development of Au nanoparticles dispersed carbon nanotube-based biosensor for the detection of paraoxon," Nanoscale, vol. 2, no. 5, pp. 806-810, 2010.

[99] X. Sun and X. Wang, "Acetylcholinesterase biosensor based on prussian blue-modified electrode for detecting organophosphorous pesticides," Biosensors and Bioelectronics, vol. 25, no. 12, pp. 2611-2614, 2010.

[100] K. Wang, H.-N. Li, J. Wu et al., " $\mathrm{TiO}_{2}$-decorated graphene nanohybrids for fabricating an amperometric acetylcholinesterase biosensor," Analyst, vol. 136, no. 16, pp. 33493354, 2011.

[101] A. C. Ion, I. Ion, A. Culetu et al., "Acetylcholinesterase voltammetric biosensors based on carbon nanostructure-chitosan composite material for organophosphate pesticides," Materials Science and Engineering C, vol. 30, no. 6, pp. 817-821, 2010.

[102] P. Norouzi, M. Pirali-Hamedani, M. R. Ganjali, and F. Faridbod, "A novel acetylcholinesterase biosensor based on chitosan-gold nanoparticles film for determination of monocrotophos using FFT continuous cyclic voltammetry," International Journal of Electrochemical Science, vol. 5, no. 10, pp. 1434-1446, 2010.

[103] K. Wang, Q. Liu, L. Dai et al., "A highly sensitive and rapid organophosphate biosensor based on enhancement of CdSdecorated graphene nanocomposite," Analytica Chimica Acta, vol. 695, no. 1-2, pp. 84-88, 2011.

[104] D. Du, X. Huang, J. Cai, and A. Zhang, "Comparison of pesticide sensitivity by electrochemical test based on acetylcholinesterase biosensor," Biosensors and Bioelectronics, vol. 23, no. 2, pp. 285289, 2007.

[105] O. Shulga and J. R. Kirchhoff, "An acetylcholinesterase enzyme electrode stabilized by an electrodeposited gold nanoparticle layer," Electrochemistry Communications, vol. 9, no. 5, pp. 935940, 2007.

[106] Y. Wei, Y. Li, Y. Qu, F. Xiao, G. Shi, and L. Jin, "A novel biosensor based on photoelectro-synergistic catalysis for flow-injection analysis system/amperometric detection of organophosphorous pesticides," Analytica Chimica Acta, vol. 643, no. 1-2, pp. 13-18, 2009.

[107] Y. Song, M. Zhang, L. Wang et al., "A novel biosensor based on acetylecholinesterase/prussian blue-chitosan modified electrode for detection of carbaryl pesticides," Electrochimica Acta, vol. 56, no. 21, pp. 7267-7271, 2011.

[108] S. Wu, F. Huang, X. Lan, X. Wang, J. Wang, and C. Meng, "Electrochemically reduced graphene oxide and Nafion nanocomposite for ultralow potential detection of organophosphate pesticide," Sensors and Actuators B, vol. 177, pp. 724-729, 2013.

[109] S. P. Sharma, L. N. S. Tomar, J. Acharya, A. Chaturvedi, M. V. S. Suryanarayan, and R. Jain, "Acetylcholinesterase inhibitionbased biosensor for amperometric detection of Sarin using single-walled carbon nanotube-modified ferrule graphite electrode," Sensors and Actuators B, 2012.

[110] S. Upadhyay, G. R. Rao, M. K. Sharma, B. K. Bhattacharya, V. K. Rao, and R. Vijayaraghavan, "Immobilization of acetylcholineesterase-choline oxidase on a gold-platinum bimetallic nanoparticles modified glassy carbon electrode for the sensitive detection of organophosphate pesticides, carbamates and nerve agents," Biosensors and Bioelectronics, vol. 25, no. 4, pp. 832-838, 2009.

[111] M. Musameh, M. R. Notivoli, M. Hickey et al., "Carbon nanotube-Web modified electrodes for ultrasensitive detection 
of organophosphate pesticides," Electrochimica Acta, vol. 101, pp. 209-215, 2013.

[112] I. Marinov, Y. Ivanov, K. Gabrovska, and T. Godjevargova, "Amperometric acetylthiocholine sensor based on acetylcholinesterase immobilized on nanostructured polymer membrane containing gold nanoparticles," Journal of Molecular Catalysis B, vol. 62, no. 1, pp. 66-74, 2010.

[113] D. Du, S. Chen, D. Song, H. Li, and X. Chen, "Development of acetylcholinesterase biosensor based on CdTe quantum dots/gold nanoparticles modified chitosan microspheres interface," Biosensors and Bioelectronics, vol. 24, no. 3, pp. 475-479, 2008.

[114] D. Du, S. Chen, J. Cai, and A. Zhang, "Immobilization of acetylcholinesterase on gold nanoparticles embedded in solgel film for amperometric detection of organophosphorous insecticide," Biosensors and Bioelectronics, vol. 23, no. 1, pp.130134, 2007.

[115] T. Wink, S. J.van Zuilen, A. Bult, and W. P. van Bennekom, "Selfassembled monolayers for biosensors," Analyst, vol. 122, no. 4, 1997.

[116] J. J. Gooding and D. B. Hibbert, "The application of alkanethiol self-assembled monolayers to enzyme electrodes," Trends in Analytical Chemistry, vol. 18, no. 8, pp. 525-533, 1999.

[117] M. Campàs, B. Prieto-Simón, and J.-L. Marty, "A review of the use of genetically engineered enzymes in electrochemical biosensors," Seminars in Cell and Developmental Biology, vol. 20, no. 1, pp. 3-9, 2009.

[118] J. S. van Dyk and B. Pletschke, "Review on the use of enzymes for the detection of organochlorine, organophosphate and carbamate pesticides in the environment," Chemosphere, vol. 82, no. 3, pp. 291-307, 2011.

[119] B. Adhikari and S. Majumdar, "Polymers in sensor applications," Progress in Polymer Science (Oxford), vol. 29, no. 7, pp. 699-766, 2004.

[120] G. Dhawan, G. Sumana, and B. D. Malhotra, "Recent developments in urea biosensors," Biochemical Engineering Journal, vol. 44, no. 1, pp. 42-52, 2009.

[121] G. A. Alonso, G. Istamboulie, T. Noguer, J.-L. Marty, and R. Muñoz, "Rapid determination of pesticide mixtures using disposable biosensors based on genetically modified enzymes and artificial neural networks," Sensors and Actuators B, vol. 164, no. 1, pp. 22-28, 2012.

[122] T. Kaku, H. I. Karan, and Y. Okamoto, "Amperometric glucose sensors based on immobilized glucose oxidase-polyquinone system," Analytical Chemistry, vol. 66, no. 8, pp. 1231-1235, 1994.

[123] L. Coche-Guerente, S. Cosnier, C. Innocent, and P. Mailley, "Development of amperometric biosensors based on the immobilization of enzymes in polymer films electrogenerated from a series of amphiphilic pyrrole derivatives," Analytica Chimica Acta, vol. 311, no. 1, pp. 23-30, 1995.

[124] A. P. Alivisatos, "Semiconductor clusters, nanocrystals, and quantum dots," Science, vol. 271, no. 5251, pp. 933-937, 1996.

[125] G. Jie, B. Liu, H. Pan, J.-J. Zhu, and H.-Y. Chen, "CdS nanocrystal-based electrochemiluminescence biosensor for the detection of low-density lipoprotein by increasing sensitivity with gold nanoparticle amplification," Analytical Chemistry, vol. 79, no. 15, pp. 5574-5581, 2007.

[126] D. Wang, A. L. Rogach, and F. Caruso, "Semiconductor quantum dot-labeled microsphere bioconjugates prepared by stepwise self-assembly," Nano Letters, vol. 2, no. 8, pp. 857-861, 2002.
[127] C. S. Pundir and N. Chauhan, "Acetylcholinesterase inhibitionbased biosensors for pesticide determination: a review," Analytical Biochemistry, vol. 429, pp. 19-31, 2012. 

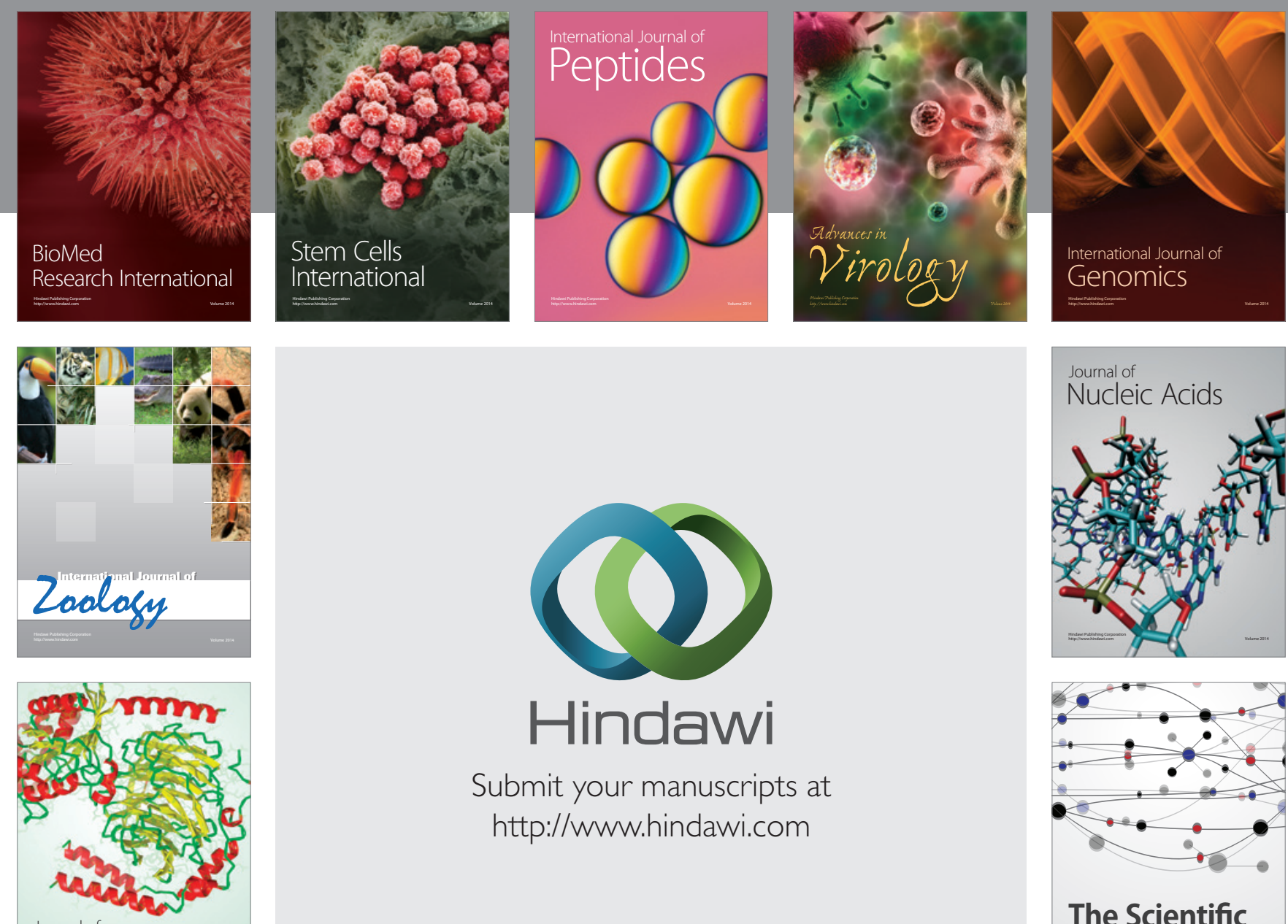

Submit your manuscripts at

http://www.hindawi.com

Journal of
Signal Transduction
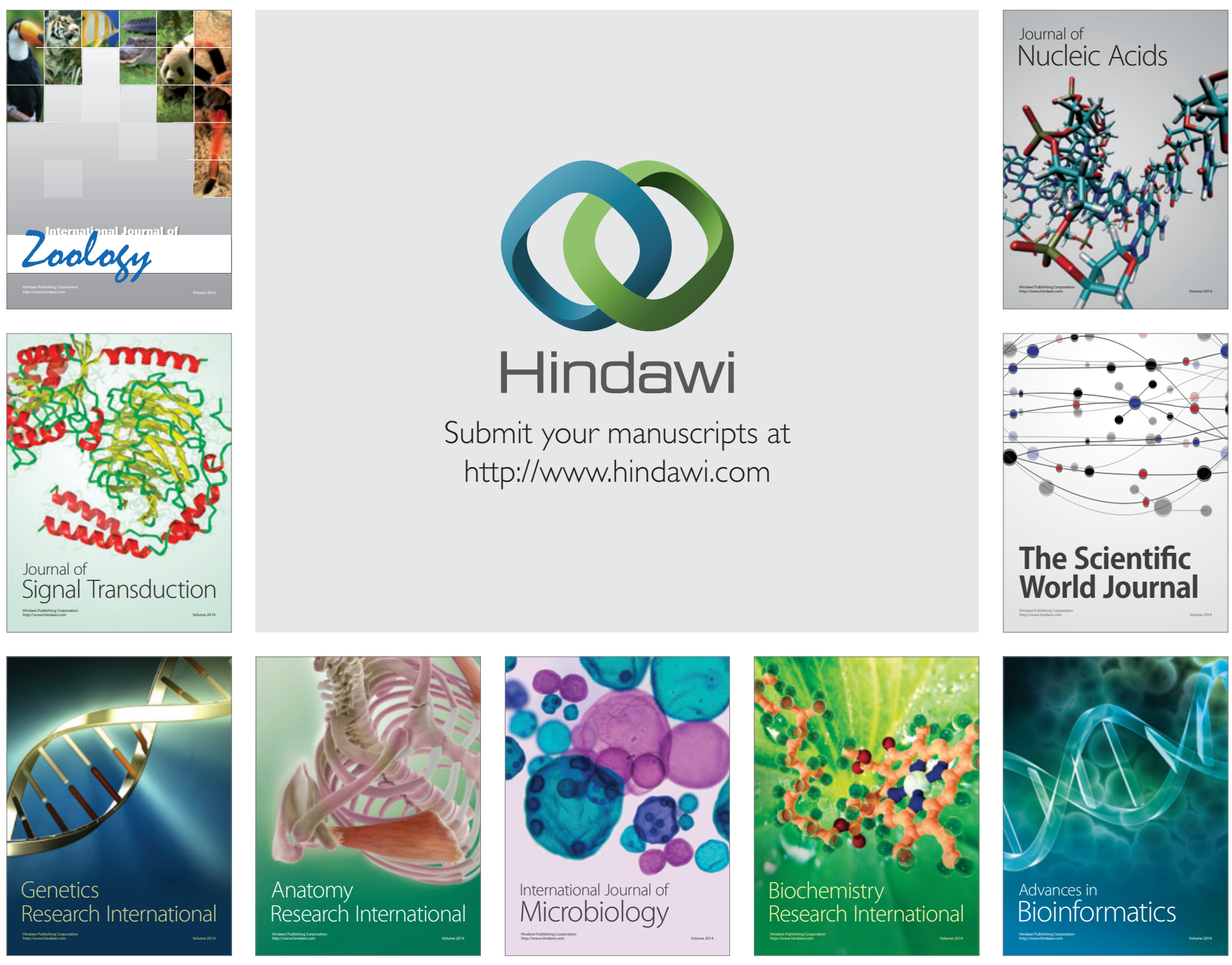

The Scientific World Journal
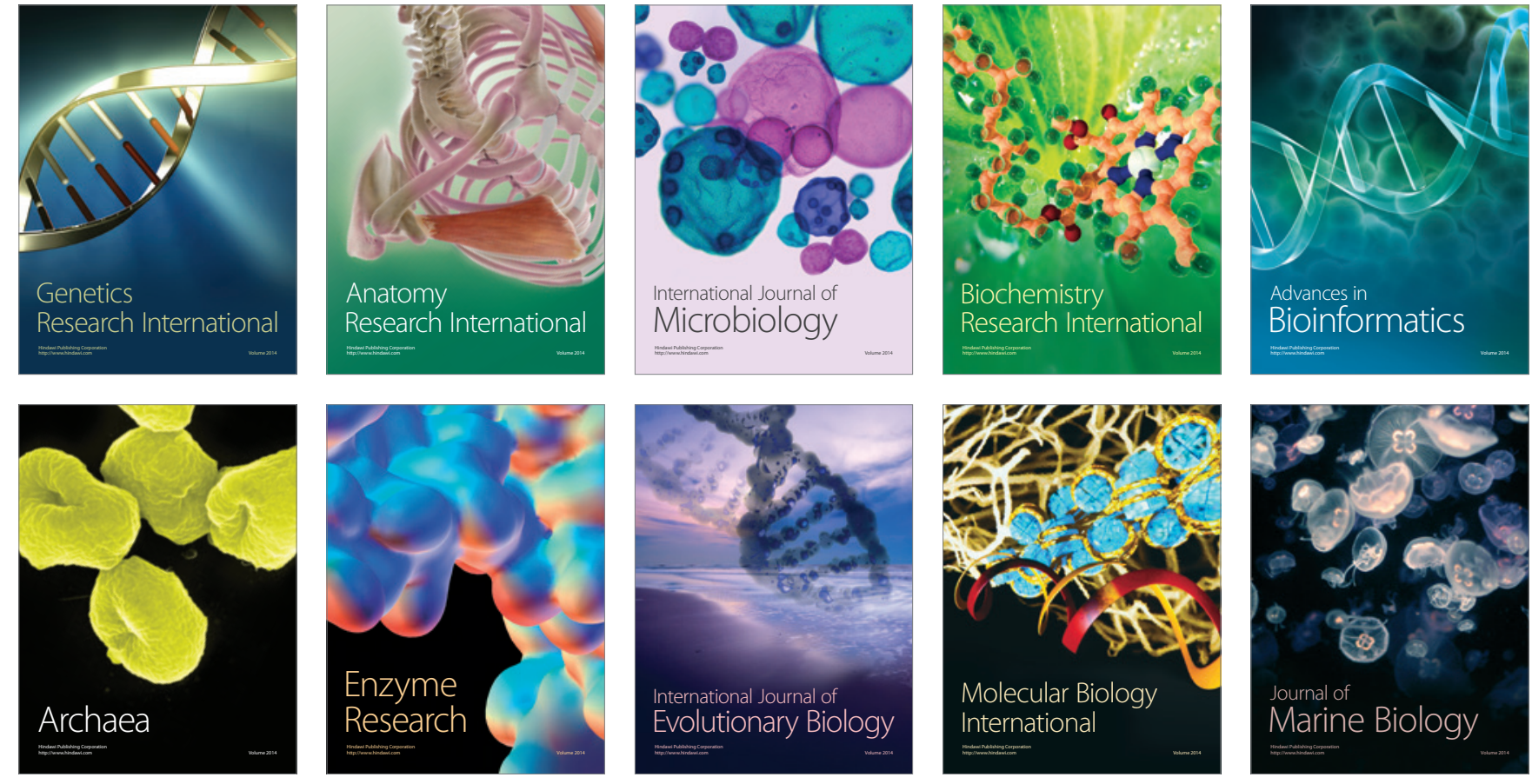